\title{
Publication of Research in Sex Roles on Lesbian, Gay, Bisexual, Transgender, and Queer (LGBTQ) Issues
}

\author{
Irene Hanson Frieze • Susan Dittrich
}

Published online: 19 April 2013

(C) Springer Science+Business Media New York 2013

In 2009, Michael Parent, one of the co-editors of this special issue, organized a symposium at the annual meeting of the American Psychological Association on Publishing LGBT Research. We presented data at that session about how Sex Roles had treated this general issue from our initial publication in 1975 through 2008. We present some of this information here, and have expanded our analysis to include publications in 2009 through 2012. As our mission statement now reads:

Sex Roles: A Journal of Research is an interdisciplinary behavioral science journal offering a feminist perspective. It publishes original research reports and review articles that illuminate the underlying processes and consequences of gender role socialization, gendered perceptions and behaviors, and gender stereotypes. The range of topics is broad, extending to gender issues in employment and work environments; interpersonal relationships; sexual orientation and identity; body image; violence against women, or intimate partners; gender role socialization; the influences of media, schools, peers and community on stereotypes; the acquisition, maintenance, and impact of stereotypes; the cultural, economic, legal and political effects of contemporary social change; or methodological issues in gender research. All papers consider the possibility of study participant gender differences in the initial statement of hypotheses and the analysis of data.

Although this has changed over the last 38 years, these general ideas have always been part of our mission.

I. H. Frieze $(\bowtie) \cdot$ S. Dittrich

Department of Psychology, University of Pittsburgh,

Pittsburgh, PA 15260, USA

e-mail: frieze@pitt.edu
Probably the biggest change in the journal over its history has been the increase in published pages. Sex Roles was initially a quarterly journal with four issues a year. In 1977, it was published 6 times a year. In 1981, it was published monthly. In 2012, we published a total of 1,524 journal pages. This included 86 regular journal articles, 19 Feminist Forum articles, 10 articles in special issues, and 32 book and media reviews. Thus, we are a high volume journal. We received a total of 642 new submissions in 2012, as well as 486 revised submissions. This includes all original research reports, Feminist Forum papers (reviews of empirical literature arguing for a particular point of view), special issue articles, and book and media reviews. We received manuscripts last year from 46 different countries. The current acceptance rate is $14 \%$ and the rejection rate is $86 \%$.

In order to examine the publication of papers relating to LGBTQ issues in Sex Roles, in 2009 we conducted a Google Scholar search using search terms of homosexual, gay, lesbian, bisexual, transgender, transsexual, and queer. We then checked to make sure each of the resulting articles did address these topics. Google Scholar returned all articles published in Sex Roles containing any of the above search terms, and we omitted some of the articles which used these terms only in the reference list. We also omitted articles where the only use of the word "gay" was a surname in a citation with no other search terms found.

The first paper we identified as meeting our criteria was published in the first year of the journal. It was an article by Joseph Pleck on paradigms of masculinity and femininity (Pleck 1975). Within our search criteria, we also noted that the top cited paper between 1975 and 2008 was an article by Carol Martin (1990) on children with nontraditional and traditional gender roles (cited by 90 articles). The second most cited was an article by Kay Deaux and Randel Hanna (1984) on the influence of gender and sexual orientation in personal ads. This was cited by 88 papers. The third most cited article was Don 
Fig. 1 Percentages of LGBTQ articles published in Sex Roles per year (1975-1993)
Percentages of LGBTQ articles published

in Sex Roles per year (1975-1993)

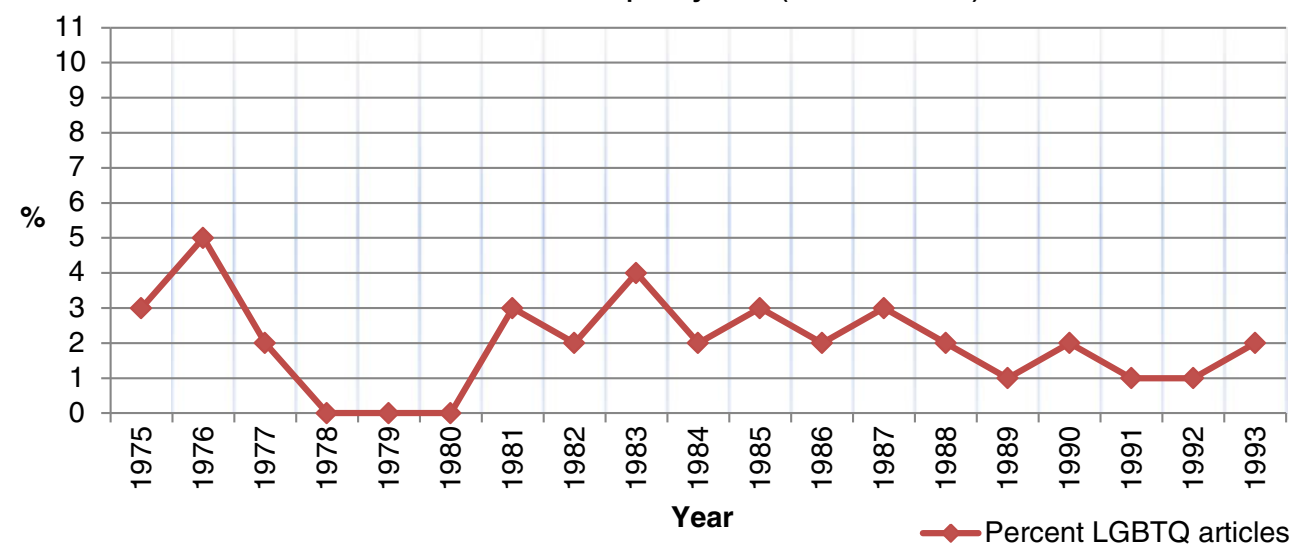

McCreary's 1994 paper on the male role and avoiding femininity, which was cited by 79 articles. Since that time, the top three cited papers are McCreary (1994) cited by 161 articles, Bernard E. Whitley Jr. (2001) cited by 159 articles, and Carol Martin (1990) cited by 155 articles. Of the articles published from 2009 to 2012, the top cited articles are Henny Bos and Theo G. M. Sandfort's (2010) article on gender identity of children in lesbian and heterosexual families (cited by 29 articles), Aaron J. Blashill and Kimberly K. Powlishta's (2009) article on gay stereotypes (cited by 22 articles), and Rebecca L. Stotzer's (2009) article on the development of positive attitudes toward the LGB community (cited by 21 articles).

In order to analyze changes over time, we divided the total number of relevant papers by the total number of papers published by year. Results are shown by year in Figs. 1 and 2. As can be seen, overall there has been an increasing trend to include more and more of these types of articles over the years of publication of the journal. Percentages vary across years, with some years having far more than others. Since we did not include the papers in this special issue, the true count for 2012, when many of these were published on-line, will be much higher.

We next looked at the content of these papers. There were two major research themes we identified in the papers: (1) Behaviors of lesbians and gays compared to comparable heterosexual groups; and (2) Attitudes about lesbians and/or gays and other sexual minorities (such as the transgendered) in comparison to other groups. Many of these studies further examine whether one group has more prejudicial attitudes than another. A major research question under studies comparing lesbians and gays with heterosexuals was whether gender or sexual orientation was a better predictor of behavior (or of attitudes). Papers reflecting this focus have appeared since the very early years of publication, and continue through the current year. The highly cited Martin (1990) paper examined gender-stereotypic behavior children. A more recent examination of this issue can be seen in C. Lynn Carr (2007). Other researchers look at these comparisons in adults. For example, Renee EngelnMaddox and her colleagues published a paper in 2011 on body surveillance as predicted by gender and sexual
Fig. 2 Percentages of LGBTQ articles published in Sex Roles per year (1994-2012)

\section{Percentages of LGBTQ articles published}

in Sex Roles per year (1994-2012)

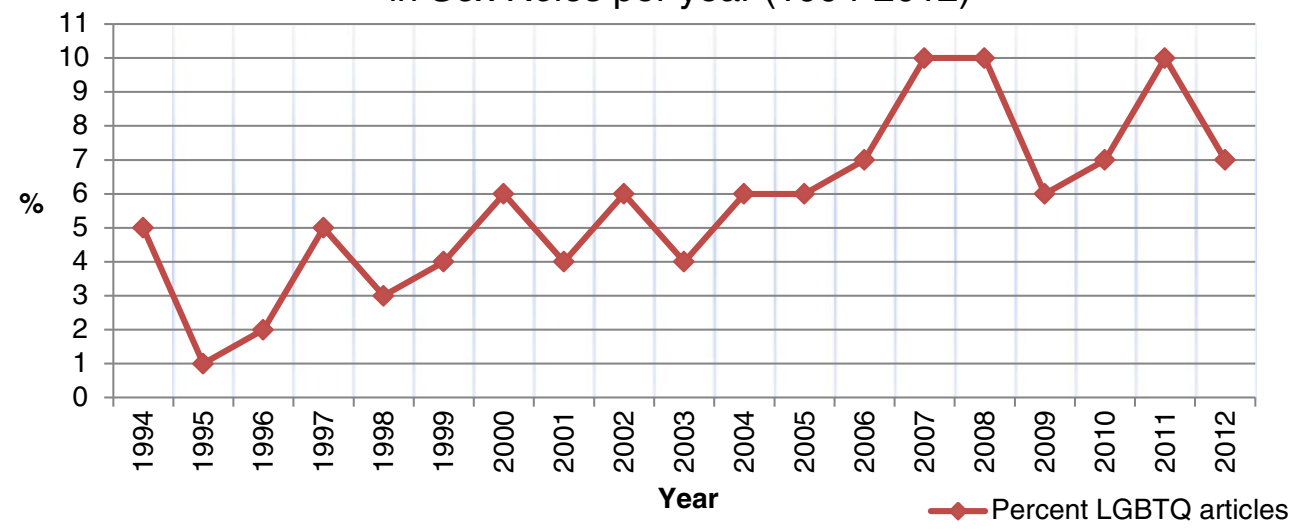


orientation (Engeln-Maddox et al. 2011). In recent years, these papers are typically not accepted, since they rarely build on what we already know-that both gender and sexual orientation predict attitudes and behavior. But, some such as Engeln-Maddox et al. add interesting new perspectives to this issue.

The topic of how LGBTQ populations are viewed by others often takes the form of assessment of stereotypes of the particular population. There were many papers on negative views of "homosexuals" in the 1970s and these continue to the present day (e.g., Whitley 2001; Whitley et al. 2011). More recently, the focus has turned to other groups such as the transgendered. There are now many scales measuring such attitudes about different LGBTQ populations (Carroll et al. 2012). Many of these scales are cited in the papers in this issue (e.g., Norton and Herek 2012). New themes relating to attitudes are concerns of men about being labeled as gay (Pompper 2010, discussed this issue as part of a larger analysis of being metrosexual), and views of victims of same-sex violence, rape or sexual harassment (e.g., DeSouza et al. 2007).

Some papers have taken the form of looking at which types of people have the most negative attitudes. The 2001 Whitley paper is probably the most cited of such papers, and provides data showing that men, relative to women, tend to have more negative views of homosexuals generally, and especially of gay men. Several papers were published in Sex Roles documenting the stereotype that lesbians were less attractive than heterosexual women (Dew 1985). Another theme we see in more than one paper is the idea that feminists are disproportionally lesbians (Ramsey et al. 2007).

More recent studies have focused on relationships of lesbians and gay males. Several papers have examined lesbians and gay men as parents (Goldberg et al. 2012; Sutfin et al. 2008). Other family dynamics of gay couples have also been a recurring theme. Studies analyzing romantic attractions of lesbians and/or gay men were published beginning in the mid-1980s (Boyden et al. 1984) and continue in recent years (Smith et al. 2011). A recent paper examines partner violence in same-gender couples (Baker et al. 2012). Another theme growing in popularity is how those labeled as lesbian or gay view themselves and how they react to the prejudice they experience in their daily lives (e.g., Gonzalez et al. 2012; Lehavot et al. 2012). A paper published in 2012 (Morgan 2012) related to the development of a heterosexual orientation. Thus, the topics do change over time, but the basic themes continue to be of interest to researchers.

In conclusion, we hope this analysis has made it clear that Sex Roles welcomes submissions relating to lesbian, gay, bisexual, transgendered or queer populations or issues. Previously published papers on these topics provide a rich source of information for those interested in these topics. The special issue included in this volume will add substantially to this information.

\section{References}

Baker, N. L., Buick, J. D., Kim, S. R., Moniz, S., \& Nava, K. L. (2012). Lessons from examining same-sex intimate partner violence. Sex Roles. doi:10.1007/s11199-012-0218-3. Advance online publication.

Blashill, A. J., \& Powlishta, K. K. (2009). Gay stereotypes: The use of sexual orientation as a cue for gender-related attributes. Sex Roles, 61, 783-793. doi:10.1007/s11199-009-9684-7.

Bos, H., \& Sandfort, T. G. M. (2010). Children's gender identity in lesbian and heterosexual two-parent families. Sex Roles, 62, 114 126. doi:10.1007/s11199-009-9704-7.

Boyden, T., Carroll, J. S., \& Maier, R. A. (1984). Similarity and attraction in homosexual males: The effects of age and masculinity-femininity. Sex Roles, 10, 939-948. doi:10.1007/BF00288516.

Carr, C. L. (2007). Where have all the tomboys gone? Women's accounts of gender in adolescence. Sex Roles, 56, 439-448. doi:10.1007/s11199-007-9183-7.

Carroll, L., Güss, D., Hutchinson, K. S., \& Gauler, A. A. (2012). How do U.S. students perceive trans persons? Sex Roles, 67, 516-527. doi:10.1007/s11199-012-0193-8.

Deaux, K., \& Hanna, R. (1984). Courtship in the personals column: The influence of gender and sexual orientation. Sex Roles, 11, 363-375. doi:10.1007/BF00287465.

DeSouza, E. R., Solberg, J., \& Elder, C. (2007). A cross-cultural perspective on judgments of woman-to-woman sexual harassment: Does sexual orientation matter? Sex Roles, 56, 457-471. doi:10.1007/s11199-007-9184-6.

Dew, M. A. (1985). The effect of attitudes on inferences of homosexuality and perceived physical attractiveness in women. Sex Roles, 12, 143-155. doi:10.1007/BF00288043.

Engeln-Maddox, R., Miller, S. A., \& Doyle, D. M. (2011). Tests of objectification theory in gay, lesbian, and heterosexual community samples: Mixed evidence for proposed pathways. Sex Roles, 65, 518-532. doi:10.1007/s11199-011-9958-8.

Goldberg, A. E., Kashy, D. A., \& Smith, J. Z. (2012). Gender-typed play behavior in early childhood: Adopted children with lesbian, gay, and heterosexual parents. Sex Roles, 67, 503-515. doi:10.1007/s11199-012-0198-3.

Gonzalez, C. A., Bockting, W. O., Beckman, L. J., \& Durán, R. E. (2012). Agentic and communal personality traits: Their associations with depression and resilience among transgender women. Sex Roles, 67, 528-543. doi:10.1007/s11199-012-0202-y.

Lehavot, K., Molina, Y., \& Simoni, J. M. (2012). Childhood trauma, adult sexual assault, and adult gender expression among lesbian and bisexual women. Sex Roles, 67, 272-284. doi:10.1007/s11199-012-0171-1.

Martin, C. L. (1990). Attitudes and expectations about children with nontraditional and traditional gender roles. Sex Roles, 22, 151165. doi: $10.1007 / \mathrm{BF} 00288188$.

McCreary, D. R. (1994). The male role and avoiding femininity. Sex Roles, 31, 517-531. doi:10.1007/BF01544277.

Morgan, E. M. (2012). Not always a straight path: College students' narratives of heterosexual identity development. Sex Roles, 66, 79-93. doi:10.1007/s11199-011-0068-4.

Norton, A. T., \& Herek, G. M. (2012). Heterosexuals' attitudes toward transgender people: Findings from a national probability sample of US adults. Sex Roles, this issue. doi: 10.1007/s11199-011-0110-6.

Parent, M. C. (Chair). (2009). Publishing LGBT Research II. Symposium conducted at the annual meeting of the American Psychological Association, San Diego, California.

Pleck, J. H. (1975). Masculinity-femininity: Current and alternative paradigms. Sex Roles, 1, 161-178. doi:10.1007/BF00288009.

Pompper, D. (2010). Masculinities, the metrosexual, and media images: Across dimensions of age and ethnicity. Sex Roles, 63, 682696. doi:10.1007/s11199-010-9870-7. 
Ramsey, L. R., Haines, M. E., Hurt, M. M., Nelson, J. A., Turner, D. L., Liss, M., \& Erchull, M. J. (2007). Thinking of others: Feminist identification and the perception of others' beliefs. Sex Roles, 56, 611-616. doi:10.1007/s11199-007-9205-5.

Smith, C. A., Konik, J. A., \& Tuve, M. V. (2011). In search of looks, status, or something else? Partner preferences among butch and femme lesbians and heterosexual men and women. Sex Roles, 64, 658-668. doi:10.1007/s11199-010-9861-8.

Stotzer, R. L. (2009). Straight allies: Supportive attitudes toward lesbians, gay men, and bisexuals in a college sample. Sex Roles, 60 , 67-80. doi:10.1007/s11199-008-9508-1.
Sutfin, E. L., Fulcher, M., Bowles, R. P., \& Patterson, C. J. (2008). How lesbian and heterosexual parents convey attitudes about gender to their children: The role of gendered environments. Sex Roles, 58, 501-513. doi:10.1007/s11199-007-9368-0.

Whitley, B. E., Jr. (2001). Gender-role variables and attitudes toward homosexuality. Sex Roles, 45, 691-721. doi:10.1023/ A:1015640318045.

Whitley, B. E., Jr., Childs, C. E., \& Collins, J. B. (2011). Differences in Black and White American college students' attitudes toward lesbians and gay men. Sex Roles, 64, 299-310. doi:10.1007/ s11199-010-9892-1. 